Troops in Uganda: from Lugard's Enlistment to the Mutiny, I891-7', by O. W. Furley; 'Taxation Problems of Federalism', by J. D. Nyhart; 'Some Preliminary Reactions to Uganda's Development Plans', by D. Walker; 'Some Aspects of the Administration of the Belgian Congo', by P. Whitaker; 'Administration and Politics in two Swahili Communities', by G. E. T. Wijeyewardene.

\title{
Nigerian Institute of Social and Economic Research Conference
}

THE Nigerian Institute of Social and Economic Research held a conference of social scientists from all parts of West Africa between Is and 20 December last. The conference was the sixth of the series started by the former West African Institute of Social and Economic Research in 1952. It took place at University College, Ibadan.

The fifty-five delegates who attended included members of the staff of N.I.S.E.R., of University College, Ibadan, the University College of Ghana, the Universities of Oxford, Edinburgh, Dakar, Stanford, and of Nigerian Government Departments.

Twenty-seven papers on subjects of economic and social relevance to West Africa were read and discussed. The proceedings will be published.

\section{Inter-African Committee on Linguistics (C.C.T.A.)}

The Inter-African Committee on Linguistics of C.C.T.A. met at Tervuren near Brussels from 29 June to I July I959. The meeting was attended by representatives from Belgium, the Federation of Rhodesia and Nyasaland, France, Portugal, the United Kingdom, and the Union of South Africa, with M. Jean-Paul Lebeuf as Secretary of the Inter-African Committee for Social Sciences.

The project for republishing rare grammars and dictionaries of African languages is now at a stage where member governments will be asked to finance the publication of ten books during the years 1960 and $196 \mathrm{r}$. The books are Armstrong: "The phonetic structure of Somali'; Christaller: A Grammar of Tshi; Laman : Dictionnaire kikongo-frangais; Endemann: Versuch einer Grammatik des Sotho; Chatelain: Grammatica elementar do Kimbundo; Smith: A Handbook of the Ila Language; Bazin: Dictionnaire bambara-francais; Goldie: Dictionary of the Efik Language; Krapf: A Dictionary of the Suaheli Language; van Warmelo: TshivendaEnglish Dictionary, or Gaden: Le Poular.

The Committee has recommended that a conference of African linguists, especially those working in African university institutions, be held under C.C.T.A. auspices in Africa in I96I. The purpose of the conference would be to plan a programme for studying the nature and development of the different linguae francae and pidgin languages used in Africa south of the Sahara, and also to find ways of studying the modifications which European languages undergo when they are used in African communities.

Other projects include the compiling of a list of African grammars written by African authors. The list will consist of the title and location of each grammar, with notes on the terminology used by the author. It will be a guide to unpublished manuscripts as well as published works. The Committee also intends to issue an annual register of field work which is in progress on African languages.

\section{[Communicated by Guy Atkins]}

